\title{
25 Research Soure \\ HIV Diagnosis Time Differentiates ART Initiation: Implications from a Prospective Cohort Study in China
}

\section{YANG Tinglong}

Sun Yat-sen University

\section{Xueying Yang}

Arnold School of Public Health, University of South Carolina, Columbia

\section{Linghua Li}

GuangZhou Eighth People`s Hospital, China

\section{Huifang Xu}

Guangzhou Center for Disease Control and Prevention, Guangzhou, China

\section{Lirui Fan}

Guangzhou Center for Disease Control and Prevention, Guangzhou, China

\section{Quanmin Li}

GuangZhou Eighth People`s Hospital, China

\section{Xiaoyan Fan}

Sun Yat-sen University

\section{Weiyi Chen}

Sun Yat-sen University

\section{Xuan Du}

Sun Yat-sen University

\section{Chun Hao}

Sun Yat-sen University

\section{Jinghua Li}

Sun Yat-sen University

\section{Yuantao Hao}

Sun Yat-sen University

Jing Gu ( $\nabla$ gujing5@mail.sysu.edu.cn )

Sun Yat-sen University https://orcid.org/0000-0001-5436-2339

\section{Research}

Keywords: HIV, ART, perceptions, cohort, China

Posted Date: December 3rd, 2020

DOI: https://doi.org/10.21203/rs.3.rs-117179/v1

License: (ㄷ) (i) This work is licensed under a Creative Commons Attribution 4.0 International License. Read Full License 


\section{Abstract}

Background: We estimated the predictive effects of ART-related perceptions on the actual ART uptake behavior among ART naïve PLWH stratified by different time of HIV diagnosis under the new strategy.

Methods: A prospective cohort study was conducted among ART naïve PLWH in Guangzhou, China from June 2016 to June 2017. Cox regression model was used to evaluate the predictive effects of ART-related perceptions on ART initiation among PLWH stratified by different timepoint of HIV diagnosis (i.e., before or after the update of the new treatment policy).

Results: Among 411 participants, 150 and 261 were diagnosed before (pre-scaleup group) and after (post-scaleup group) the implementation of the new strategy, respectively. The ART initiation rate in the post-scaleup group (88.9\%) was higher than that in the pre-scaleup group (73.3\%) $(p<0.001)$. A significant difference of mean score was detected in each HBM construct between pre- and post- scaleup groups $(p<0.05)$. After adjusting for significant background variables, among all participants, only the self-efficacy (adjusted HR (HRa) $=1.23,95 \%$ C.I.: 1.06 to $1.43, p=0.006)$, has a predictive effect on ART initiation; in pre-scaleup group, all constructs of HBM-related ART perceptions were predictors of ART initiation (HRa=0.71 to 1.83, $p<0.05)$, while in post-scaleup group, no significant difference was found in each construct $(p>0.05)$.

Conclusions: The ART initiation rate was high particularly among participants who diagnosed after the new treatment strategy. The important role of the time of HIV diagnosis on ART initiation identified in this study suggested that future implementation interventions may consider to modify the ART-related perceptions for HIV patients who diagnosed before the implementation of the new ART strategy, while expand the accessibility of ART service for those who diagnosed after the implementation of the new strategy.

\section{Introduction}

The HIV epidemic remained a global challenge [1]. Based on recent evidence that early antiretroviral therapy (ART) initiation was effective in preventing HIV transmission and slowing the progression of HIV-related diseases as compared to delayed treatment [2-4], WHO proposed the 'Treatment as Prevention' strategy in 2013, and recommended immediate ART for all people living with HIV (PLWH) irrespective of their CD4 counts (CD4) in 2015 [5]. Globally the ART coverage was 59\% in 2017 [1], and the rate varies across countries (37-72\%) [6]. In China, by the end of September 2018, the reported number of PLWH was 850,000 , and about 80,000 people are newly diagnosed every year [7]. In June 2016, China launched the new ART strategy which provides free ART irrespective of clinical stage and CD4 count and immediate initiation after diagnosis to all PLWH (hereinafter referred to as 'the New Strategy') [8].

Existing literature suggested that the factors associated with ART initiation included socio-demographic characteristics (e.g., age, education level) [9, 10], HIV infection-related characteristics (e.g., route of transmission, CD4 levels) [11, 12], perceptions about ART (e.g., knowledge, treatment intention) $[13,14]$ and psychosocial factors (e.g., depression, social support) [15-17]. In addition, the evolution of ART guidelines from advocating a cautious application to a near universal approach may also have crucial improvement on ART initiation. A study in Ethiopia found that PLWH who were diagnosed after year 2008 (WHO guideline increased the threshold of CD4 to initiate ART from 200 to 350 cells/ul in 2008) were more likely to initiate ART than those diagnosed before 2008 (18). Another study in South Africa found that among PLWH with CD4 between 201 to 350 cells/ul, those diagnosed after 2011 (South Africa guideline increased the threshold of CD4 to start ART from 200 to 350 cells/ul in 2011) had higher ART initiation rate than those previously diagnosed [19]. Research in China among HIV positive adolescents [20] and MSM [21] showed similar results. These cohort studies mentioned above confirmed the positive effects of broadened spectrum of eligible individuals on improving timely treatment and ART coverage.

However, there is still a significant number of PLWH who had not initiated ART despite the scale-up strategy, leading to a gap to the UNAIDS 90\% ART coverage goal [22]. How these potential ART users (e.g., past and recent diagnoses) perceive the treatment is essential to the implementation of the new strategy, as perceptions are known to be strong predictors of actual behaviors [14]. According to literature review, most existing research among ART naïve PLWH focused on the intention of 
early ART. For example, research in UK found that 43-47\% ART naïve PLWH were willing to start ART [23]; research in Australia found that $72 \%$ of HIV positive men who have sex with men (MSM) believed the necessity to start ART as early as possible[24]. Studies in China also reported that early ART was acceptable for over $60 \%$ of HIV positive MSM $[21,25,26]$. However, the above studies focused on ART intention and perceptions through cross-sectional designs. So far there is a lack of studies investigating how ART-related perceptions predict actual ART initiation behaviors prospectively after the implementation of new ART strategy.

Behavioral theories help people understand, interpret and improve health-related behaviors [27, 28]. There is a number of behavioral theories being successfully applied in HIV/AIDS area, among which the Health Belief Model (HBM) is one of the most widely used. The HBM has been applied to study late ART initiation [29], ART adherence [30, 31], HIV testing [32], and was also successfully used to guide behavioral interventions [33,34]. According to HBM, perceived severity, perceived susceptibility, perceived barriers, perceived benefits and self-efficacy are the key constructs, which can be used as potential predictors of ART initiation [27, 28]. How ART naïve PLWH perceive the treatment, whether different subgroups (e.g., PLHW diagnosed before and after the implementation of new strategy) have different perceptions, and how such differences affect ART initiation behavior? Answers to these questions are warranted when implementing the new ART strategy.

This cohort study was conducted right after the New ART strategy (universal ART) being implemented. We aimed to investigate ART-related perceptions, ART initiation behaviors and the predictive effects of perceptions on ART initiation among ART naïve PLWH in China. As the time of HIV diagnosis (before or after the implementation of the new strategy) may affect PLWH's perceptions toward ART and may lead to different behaviors, we also conducted the subgroup analyses and examined the interactions between perceptions and the time of diagnosis on ART initiation.

\section{Methods}

\section{Study design and population}

This cohort study was conducted from June 2016 to June 2018 in Guangzhou, the capital city of Guangdong Province (China started the new ART strategy since June 1st, 2016) (8). By the end of 2015, 7,311 HIV cases had been reported in Guangzhou and 5,056 PLWH (69.2\%) were receiving ART (Guangzhou Yearbook, 2016). Six out of 11 districts with the highest HIV prevalence in Guangzhou were selected as the study sites, among which 3 were urban and 3 were suburb districts. All participants were recruited during the first year of the study period and followed up for at least 12 months to assess ART initiation behaviors.

The study population comprised of individuals who were aged $\geq 18$ years, confirmed as HIV positive, clinically eligible for ART, never experienced ART before, and could provide informed consent. In total, 439 eligible participants were recruited, of which 411 (93.6\%) finished the baseline survey. Ethical approval was obtained from the Ethics Committee of the School of Public Health, Sun Yat-sen University.

\section{Data collection}

According to National Practical Guideline for the Follow-up and Management of PLWH, district-level Centers for Disease Control and Prevention (CDC) or Community Healthcare Centers (CHCs) (sub-district level) are responsible for providing routine care of PLWH in community, including regular follow up and health education [35]. In this study, the trained health care workers at CDC or CHCs contacted all PLWH in the jurisdiction who met the inclusion criteria and invited them to participate in the study. Potential participants were briefed about the study design, ensured the confidentiality issues, and emphasized that refusal to participate would not affect their access to any regular health care services. After informed consent, face-to-face interviews were administered in separate private rooms using structured questionnaires.

\section{Measurements}




\section{Background information}

Background information included socio-demographic characteristics (e.g., age, gender, income) and HIV-related health status (e.g., time of HIV diagnosis, latest CD4 count) (Table 1). Participants were dichotomized by different time of HIV diagnosis into pre-scaleup group (before June 1st, 2016: the implementation of the new strategy) and post-scaleup group (after June 1st, 2016). 
Table 1

Profiles of participants diagnosed before and after implementing the new ART strategy $(n=411)$

\begin{tabular}{|c|c|c|c|c|}
\hline & $\begin{array}{l}\text { All } \\
n(\%)\end{array}$ & $\begin{array}{l}\text { Diagnosed before implementing } \\
\text { the new strategy } \\
n(\%)\end{array}$ & $\begin{array}{l}\text { Diagnosed after implementing } \\
\text { the new strategy } \\
n(\%)\end{array}$ & $P$ \\
\hline \multicolumn{5}{|l|}{$\begin{array}{l}\text { Socio-demographic } \\
\text { characteristics }\end{array}$} \\
\hline Gender & & & & 0.024 \\
\hline Male & $\begin{array}{l}389 \\
(94.6)\end{array}$ & $137(91.3)$ & 252 (96.6) & \\
\hline Female & $\begin{array}{l}22 \\
(5.4)\end{array}$ & $13(8.7)$ & $9(3.4)$ & \\
\hline Age (years, mean \pm s.d.) & $\begin{array}{l}32.8 \pm \\
10.6\end{array}$ & $32.7 \pm 9.8$ & $32.9 \pm 11.1$ & 0.600 \\
\hline Age (years) & & & & 0.603 \\
\hline$<=25$ & $\begin{array}{l}106 \\
(25.8)\end{array}$ & $35(23.3)$ & $71(27.2)$ & \\
\hline $25 \sim 35$ & $\begin{array}{l}172 \\
(41.8)\end{array}$ & $67(44.7)$ & $105(40.2)$ & \\
\hline$>35$ & $\begin{array}{l}133 \\
(32.4)\end{array}$ & $48(32.0)$ & $85(32.6)$ & \\
\hline Ethnicity & & & & 0.003 \\
\hline Han & $\begin{array}{l}384 \\
(93.4)\end{array}$ & $133(88.7)$ & $251(96.2)$ & \\
\hline Other & $\begin{array}{l}27 \\
(6.6)\end{array}$ & $17(11.3)$ & $10(3.8)$ & \\
\hline Education & & & & 0.031 \\
\hline $\begin{array}{l}\text { Junior high school and } \\
\text { below }\end{array}$ & $\begin{array}{l}113 \\
(27.5)\end{array}$ & $50(33.3)$ & $63(24.1)$ & \\
\hline Secondary school & $\begin{array}{l}128 \\
(31.1)\end{array}$ & $50(33.3)$ & $78(29.9)$ & \\
\hline College or above & $\begin{array}{l}170 \\
(41.4)\end{array}$ & $50(33.3)$ & $120(46.0)$ & \\
\hline Monthly income (RMB) & & & & 0.522 \\
\hline$<=3000$ (434 USD) & $\begin{array}{l}154 \\
(37.7)\end{array}$ & $55(37.2)$ & $99(38.1)$ & \\
\hline $\begin{array}{l}3000-5000(434 \sim 723 \\
\text { USD) }\end{array}$ & $\begin{array}{l}144 \\
(35.3)\end{array}$ & $57(38.5)$ & $87(33.5)$ & \\
\hline > 5000 (723 USD) & $\begin{array}{l}110 \\
(27.0)\end{array}$ & $36(24.3)$ & $74(28.5)$ & \\
\hline Current marital status & & & & 0.384 \\
\hline Single & $\begin{array}{l}255 \\
(62.0)\end{array}$ & $99(66.0)$ & $156(59.8)$ & \\
\hline
\end{tabular}




\begin{tabular}{|c|c|c|c|c|}
\hline & $\begin{array}{l}\text { All } \\
n(\%)\end{array}$ & $\begin{array}{l}\text { Diagnosed before implementing } \\
\text { the new strategy } \\
n(\%)\end{array}$ & $\begin{array}{l}\text { Diagnosed after implementing } \\
\text { the new strategy } \\
n(\%)\end{array}$ & $P$ \\
\hline Married/cohabitation & $\begin{array}{l}103 \\
(25.1)\end{array}$ & $32(21.3)$ & $71(27.2)$ & \\
\hline Separated/divorced/other & $\begin{array}{l}53 \\
(12.9)\end{array}$ & $19(12.7)$ & $34(13.0)$ & \\
\hline Household registration & & & & 0.304 \\
\hline Guangzhou & $\begin{array}{l}94 \\
(22.9)\end{array}$ & $28(18.8)$ & $66(25.3)$ & \\
\hline $\begin{array}{l}\text { Other cities of } \\
\text { Guangdong Province }\end{array}$ & $\begin{array}{l}116 \\
(28.3)\end{array}$ & $43(28.9)$ & $73(28.0)$ & \\
\hline Other province & $\begin{array}{l}200 \\
(48.8)\end{array}$ & 78 (52.3) & $122(46.7)$ & \\
\hline Residential district & & & & 0.384 \\
\hline Urban & $\begin{array}{l}288 \\
(70.1)\end{array}$ & 109 (72.7) & $179(68.6)$ & \\
\hline Suburb & $\begin{array}{l}123 \\
(29.9)\end{array}$ & $41(27.3)$ & $82(31.4)$ & \\
\hline \multicolumn{5}{|l|}{$\begin{array}{l}\text { HIV infection-related } \\
\text { conditions }\end{array}$} \\
\hline Route of HIV infection & & & & 0.035 \\
\hline Heterosexual & $\begin{array}{l}89 \\
(21.7)\end{array}$ & $39(26.2)$ & $50(19.2)$ & \\
\hline Homosexual & $\begin{array}{l}301 \\
(73.2)\end{array}$ & $99(66.4)$ & $202(77.4)$ & \\
\hline $\begin{array}{l}\text { Others (unknown, } \\
\text { injecting drug use) }\end{array}$ & $\begin{array}{l}20 \\
(4.9)\end{array}$ & $11(7.4)$ & $9(3.4)$ & \\
\hline Latest CD4 cell counts & & & & $\begin{array}{l}<.001 \\
0.001\end{array}$ \\
\hline$<=350$ & $\begin{array}{l}226 \\
(55.0)\end{array}$ & $54(36.0)$ & $172(65.9)$ & \\
\hline $350-500$ & $\begin{array}{l}121 \\
(29.4)\end{array}$ & $60(40.0)$ & $61(23.4)$ & \\
\hline$>500$ & $\begin{array}{l}64 \\
(15.6)\end{array}$ & $36(24.0)$ & $28(10.7)$ & \\
\hline
\end{tabular}


Table 1

(continued)

\begin{tabular}{|c|c|c|c|c|}
\hline & $\begin{array}{l}\text { All } \\
n(\%)\end{array}$ & $\begin{array}{l}\text { Diagnosed before implementing } \\
\text { the new strategy } \\
n(\%)\end{array}$ & $\begin{array}{l}\text { Diagnosed after implementing } \\
\text { the new strategy } \\
n(\%)\end{array}$ & $P$ \\
\hline Self-reported health status & & & & 0.182 \\
\hline Very good/good & $\begin{array}{l}168 \\
(40.9)\end{array}$ & $70(46.7)$ & $98(37.5)$ & \\
\hline Not good or poor & $\begin{array}{l}213 \\
(51.8)\end{array}$ & $71(47.3)$ & $142(54.4)$ & \\
\hline Poor/very poor & $\begin{array}{l}30 \\
(7.3)\end{array}$ & $9(6.0)$ & $21(8.0)$ & \\
\hline \multicolumn{5}{|l|}{$\begin{array}{l}\text { HBM-related ART } \\
\text { perceptions (mean } \pm \text { s.d.) }\end{array}$} \\
\hline Perceived severity & $\begin{array}{l}4.1 \pm \\
0.7\end{array}$ & $3.9 \pm 0.7$ & $4.2 \pm 0.7$ & $<.001$ \\
\hline Perceived susceptibility & $\begin{array}{l}4.3 \pm \\
0.8\end{array}$ & $4.1 \pm 0.8$ & $4.3 \pm 0.8$ & 0.001 \\
\hline Perceived benefits & $\begin{array}{l}4.2 \pm \\
0.6\end{array}$ & $4.1 \pm 0.7$ & $4.2 \pm 0.6$ & 0.012 \\
\hline Perceived barriers & $\begin{array}{l}3.1 \pm \\
0.7\end{array}$ & $3.2 \pm 0.7$ & $3.1 \pm 0.7$ & 0.028 \\
\hline Self-efficacy & $\begin{array}{l}4.2 \pm \\
0.8\end{array}$ & $4.0 \pm 0.9$ & $4.4 \pm 0.6$ & $\langle .001$ \\
\hline
\end{tabular}

\section{HBM-related ART perceptions}

The HBM-based items of ART perceptions were developed through literature review, in-depth interviews with 15 PLWH, and focused group discussions. The response categories of the questions in the first four constructs were rated on a five-point Likert scale (1='extremely disagree', 5='extremely agree.').

Perceived severity was measured by four items, referring to the individual's recognition of the adverse consequences of not being treated in time (e.g., 'If you do not get treatment in time, the chance of virological failure will increase in the future'). Higher scores represented stronger belief in the serious consequences if not starting ART.

Perceived susceptibility in this study was the likelihood of transmitting HIV to one's HIV-negative sexual partner(s) and was measured by 'Non-timely participation in treatment will increase the chances of HIV transmission to sexual partners.' A higher score indicated stronger belief in the chances of HIV transmission if not starting ART.

Perceived benefits were measured by six items, referring to the individual's recognition of the benefits of timely participation in treatment (e.g., 'Starting ART may increase my CD4 counts effectively'). Higher scores indicated higher perceived benefits of starting ART.

Perceived barriers were measured by six items, referring to obstacles that an individual think they may encounter if they initiate ART (e.g., 'Early ART may lead to early side effects'). Higher scores indicated stronger belief in barriers if starting ART.

Self-efficacy was measured by five items, referring to the individual's confidence in their ability to participate in treatment successfully (e.g., 'How confident are you that you will schedule your personal and work life in order to start ART?'). 
Responses were measured on a five-point scale ('not', 'a little', 'not sure', 'some' and 'very'). Higher scores represented a higher level of self-efficacy to start ART immediately.

The above scales showed good internal consistency with Cronbach's alpha coefficients ranging from 0.79 to 0.92 (Table 2). For item analyses, the responses were dichotomized (e.g., agree/extremely agree, neutral/disagree/extremely disagree). 
Table 2

HBM-related ART perceptions of participants diagnosed before and after implementing the new ART strategy

\begin{tabular}{|c|c|c|c|c|}
\hline & $\begin{array}{l}\text { All } \\
n(\%)\end{array}$ & $\begin{array}{l}\text { Diagnosed before } \\
\text { implementing the new } \\
\text { strategy } \\
n(\%)\end{array}$ & $\begin{array}{l}\text { Diagnosed after } \\
\text { implementing the new } \\
\text { strategy } \\
n(\%)\end{array}$ & $P$ \\
\hline \multicolumn{5}{|l|}{ Perceived severity a (Agree/extremely agree) } \\
\hline $\begin{array}{l}\text { Not starting ART may lead to poor treatment } \\
\text { effect. }\end{array}$ & $\begin{array}{l}361 \\
(87.8)\end{array}$ & $117(78.0)$ & $244(93.5)$ & $<.001$ \\
\hline $\begin{array}{l}\text { Not starting ART may increase the possibility of } \\
\text { treatment failure }\end{array}$ & $\begin{array}{l}344 \\
(83.7)\end{array}$ & $113(75.3)$ & $231(88.5)$ & 0.001 \\
\hline $\begin{array}{l}\text { Not starting ART may accelerate progress of } \\
\text { AIDS }\end{array}$ & $\begin{array}{l}370 \\
(90.0)\end{array}$ & $123(82.0)$ & $247(94.6)$ & <. 001 \\
\hline Not starting ART may lead to drug resistance & $\begin{array}{l}287 \\
(69.8)\end{array}$ & $87(58.0)$ & $200(76.6)$ & <. 001 \\
\hline \multicolumn{5}{|l|}{ Perceived susceptibility (Agree/extremely agree) } \\
\hline $\begin{array}{l}\text { Not starting ART may increase the possibility of } \\
\text { transmitting HIV to my sexual partner }\end{array}$ & $\begin{array}{l}367 \\
(89.3)\end{array}$ & $129(86.0)$ & $238(91.2)$ & 0.102 \\
\hline \multicolumn{5}{|l|}{ Perceived benefits ${ }^{\text {b }}$ (Agree/extremely agree) } \\
\hline $\begin{array}{l}\text { Starting ART may increase my CD } 4 \text { cell counts } \\
\text { effectively }\end{array}$ & $\begin{array}{l}372 \\
(90.5)\end{array}$ & $133(88.7)$ & $239(91.6)$ & 0.333 \\
\hline $\begin{array}{l}\text { Starting ART may promote the reconstitution of } \\
\text { my immune system effectively }\end{array}$ & $\begin{array}{l}364 \\
(88.6)\end{array}$ & $130(86.7)$ & $234(89.7)$ & 0.359 \\
\hline $\begin{array}{l}\text { Starting ART may reduce the possibility of drug } \\
\text { resistance }\end{array}$ & $\begin{array}{l}281 \\
(68.4)\end{array}$ & $95(63.3)$ & $186(71.3)$ & 0.096 \\
\hline $\begin{array}{l}\text { Starting ART may reduce the possibility of drug } \\
\text { complications }\end{array}$ & $\begin{array}{l}378 \\
(92.0)\end{array}$ & $133(88.7)$ & 245 (93.9) & 0.062 \\
\hline $\begin{array}{l}\text { Starting ART may prolong life and reduce the } \\
\text { possibility of death }\end{array}$ & $\begin{array}{l}366 \\
(89.1)\end{array}$ & $131(87.3)$ & $235(90.0)$ & 0.398 \\
\hline $\begin{array}{l}\text { Starting ART may reduce the possibility of } \\
\text { transmitting HIV to others }\end{array}$ & $\begin{array}{l}342 \\
(83.2)\end{array}$ & $121(80.7)$ & $221(84.7)$ & 0.295 \\
\hline \multicolumn{5}{|l|}{ Perceived barriers ${ }^{\mathrm{C}}$ (Agree/extremely agree) } \\
\hline Early ART may lead to early side effects & $\begin{array}{l}162 \\
(39.4)\end{array}$ & $61(40.7)$ & $101(38.7)$ & 0.694 \\
\hline Early ART may lead to early drug resistance & $\begin{array}{l}107 \\
(26.0)\end{array}$ & $38(25.3)$ & $69(26.4)$ & 0.806 \\
\hline $\begin{array}{l}\text { Early ART leads to early uptake of a lifelong } \\
\text { medication burden }\end{array}$ & $\begin{array}{l}235 \\
(57.2)\end{array}$ & $93(62.0)$ & $142(54.4)$ & 0.134 \\
\hline Early ART may interfere with life & $\begin{array}{l}142 \\
(34.5)\end{array}$ & $61(40.7)$ & $81(31.0)$ & 0.053 \\
\hline Early ART may cause an economic burden & $\begin{array}{l}128 \\
(31.1)\end{array}$ & $55(36.7)$ & $73(28.0)$ & 0.067 \\
\hline \multicolumn{5}{|c|}{${ }^{\text {a }}$ Cronbach's alpha coefficient $=0.896 ;{ }^{b}$ Cronbach's alpha coefficient $=0.922 ;{ }^{c}$ Cronbach's alpha coefficient $=0.792 ;$} \\
\hline d Cronbach's alpha coefficient $=0.892$ & & & & \\
\hline
\end{tabular}




\begin{tabular}{|c|c|c|c|c|}
\hline & $\begin{array}{l}\text { All } \\
n(\%)\end{array}$ & $\begin{array}{l}\text { Diagnosed before } \\
\text { implementing the new } \\
\text { strategy } \\
n(\%)\end{array}$ & $\begin{array}{l}\text { Diagnosed after } \\
\text { implementing the new } \\
\text { strategy } \\
n(\%)\end{array}$ & $P$ \\
\hline $\begin{array}{l}\text { Early ART may increase the possibility of } \\
\text { disclosure of one's infection status }\end{array}$ & $\begin{array}{l}194 \\
(47.2)\end{array}$ & $84(56.0)$ & $110(42.1)$ & 0.007 \\
\hline \multicolumn{5}{|l|}{ Self-efficacy d (Some/very) } \\
\hline $\begin{array}{l}\text { How confident are you that you will start ART } \\
\text { now? }\end{array}$ & $\begin{array}{l}273 \\
(66.4)\end{array}$ & $90(60.0)$ & $183(70.1)$ & 0.037 \\
\hline $\begin{array}{l}\text { How confident are you that you will prepare to } \\
\text { start ART? }\end{array}$ & $\begin{array}{l}331 \\
(80.5)\end{array}$ & $102(71.3)$ & $124(85.8)$ & $\hat{0.001}$ \\
\hline $\begin{array}{l}\text { How confident are you that you will schedule } \\
\text { your personal and work life in order to start } \\
\text { ART? }\end{array}$ & $\begin{array}{l}312 \\
(75.9)\end{array}$ & $100(66.7)$ & $212(81.2)$ & 0.001 \\
\hline $\begin{array}{l}\text { How confident are you to participate in antiviral } \\
\text { treatment in the next six months? }\end{array}$ & $\begin{array}{l}330 \\
(80.3)\end{array}$ & $101(67.3)$ & $229(87.7)$ & $\langle .001$ \\
\hline $\begin{array}{l}\text { How confident are you to participate in antiviral } \\
\text { therapy in the coming year? }\end{array}$ & $\begin{array}{l}341 \\
(83.0)\end{array}$ & 107 (71.3) & $234(89.7)$ & ¿. 001 \\
\hline \multicolumn{5}{|c|}{${ }^{\text {a }}$ Cronbach's alpha coefficient $=0.896 ;{ }^{b}$ Cronbach's alpha coefficient $=0.922 ;{ }^{c}$ Cronbach's alpha coefficient $=0.792 ;$} \\
\hline d Cronbach's alpha coefficient $=0.892$ & & & & \\
\hline
\end{tabular}

\section{Primary outcome}

The primary outcome was ART initiation, which was defined as the PLWH started ART for the first time. Their ART initiation behaviors were tracked by using the National HIV/AIDS Comprehensive Information System of China's Disease Prevention and Control information system.

\section{Statistical analysis}

In between-group comparison of the background information (participants diagnosed before or after the new strategy), $t$ test, Chi-square or rank sum test was performed accordingly. Kaplan-Meier method was used to calculate the treatment rate of the two subgroups and Log-rank test was used to test the difference.

Univariate cox regression models were fitted to assess the associations between the background variables and ART initiation in all participants. Variables with a $p<0.1$ were included as candidates in the multivariate stepwise cox regression models, and variables with a $p<0.05$ were defined as potential confounders. The associations between HBM-related ART perceptions and ART initiation was calculated by both univariate and multivariate analysis (adjusting for potential confounders). The same method was used for subgroup analysis. The results were presented as hazard ratios (HR) with $95 \%$ confidence intervals (C.I.). The significance of interaction effects of time of HIV diagnosis variable on the associations between the HBMrelated ART perceptions and ART initiation was tested using multiple cox regression models. A total of 5 interaction models were fitted (each construct of HBM-related ART perceptions $\times$ time of HIV diagnosis). SPSS for Windows (version 25.0; SPSS, Chicago, Illinois) was used for statistical analyses. A $p$ value $<0.05$ was considered statistically significant.

\section{Results}

\section{Participants profile}


Of 411 participants, 150 (36.5\%) and 261 (63.5\%) were diagnosed before (pre-scaleup group) or after (post-scaleup group) implementing the new strategy, respectively. Most participants were male (94.6\%), Han ethnicity (93.4\%), single (62.0\%), attained college degree or above (41.4\%), and self-report as homosexual HIV transmission route (73.2\%). The mean age was 32.8 years (standard deviation $(S D)=10.6)$ and the mean value of their latest CD4 count were 347.8 cells/ul $(S D=182.9)$. Compared with pre-scaleup group, participants in the post-scaleup group are more likely to be male $(96.6 \%$ vs $91.3 \%, p=$ 0.024), self-report as homosexual HIV transmission route $(77.4 \%$ vs $66.4 \%, p=0.035)$, attained college degree or above (46.0 vs $33.3 \%, p=0.031$ ), and have a lower CD 4 count (308.9 vs 415.5, $p<0.001$ ) (Table 1 ).

\section{ART-related perception}

The difference of mean scores is significant in each construct of HBM-related ART perception between pre- and post-scaleup groups $(p<0.05)$. Specifically, the participants in the post-scaleup group perceived higher severity $(p<0.001)$, higher susceptibility $(p=0.001)$, higher benefits $(p=0.012)$, while lower perceived barriers $(p=0.028)$ and higher self-efficacy ( $p<$ 0.001 ) than those in the pre-scaleup group. Regarding specific items of HBM-related ART perception scale, $69.8-90.0 \%$ of all participants believe that not timely initiate ART will have serious consequences (e.g., treatment failure), especially in the postscaleup group (76.6-94.6\%), which were higher than that in the pre-scaleup group $(58.0-82.0 \%, p<0.05)$. Most $(89.3 \%)$ participants agree that not timely initiate ART will increase the chance of transmitting HIV to his sexual partner(s). At the same time, most participants (68.4-92.0\%) perceived benefits of timely ART initiation. There was also a substantial number of participants (26.0-57.2\%) who had concerns about ART (e.g., worried about the pill burden of taking ART regimen, the exposure of their HIV status, side effects). Compared with the post-scaleup group, the pre-scaleup group were more worried about the exposure of their HIV status when taking medication ( $56.0 \%$ vs $42.1 \%, p=0.007)$. In terms of self-efficacy, $66.4-$ 83.0\% participants were confident to initiate ART (e.g., scheduled your personal and work life in order to start ART), and the participants in the post-scaleup group (70.1-89.7\%) had more confidence than those in the pre-scaleup group (60.0-71.3\%) $(p<0.05)$ (Table 2).

\section{ART initiation}

Among all participants, 342 (83.2\%, 95\% Cl: $79.6 \%$ to $86.8 \%)$ started ART during the follow-up period. The median time interval from baseline enrollment to ART initiation of all the participants is 15 days (ranging from 1-758 days), with 65 (95\% Cl: 9.2 to 120.8$)$ days and 12 (95\% Cl: 10.5 to 13.5$)$ days in the pre-scaleup group and post-scaleup group, respectively. The ART initiation rate in the post-scaleup group (88.9\%, 95\% Cl: $85.1-92.7 \%)$ was significantly higher than that in the pre-scaleup group (73.3\%, 95\% Cl: $66.2-80.5 \%)(p<0.001)$.

\section{The predictive effect of background variables on ART initiation}

In univariate analysis of all participants, predictors of ART initiation include: older age, married/cohabited with others, living in the suburb area, higher CD4 levels, self-reported as poor health status, and diagnosed HIV after the new strategy (Table 3). In multivariate analysis (data not tabulated), participants in the post-scaleup group were more likely to initiate ART than those in the pre-scaleup group (multivariate $\mathrm{HR}\left(\mathrm{HR}_{\mathrm{m}}\right)=2.08,95 \% \mathrm{Cl}: 1.65$ to $\left.2.64, p<0.001\right)$. 
Table 3

Associations between background variables and ART initiation

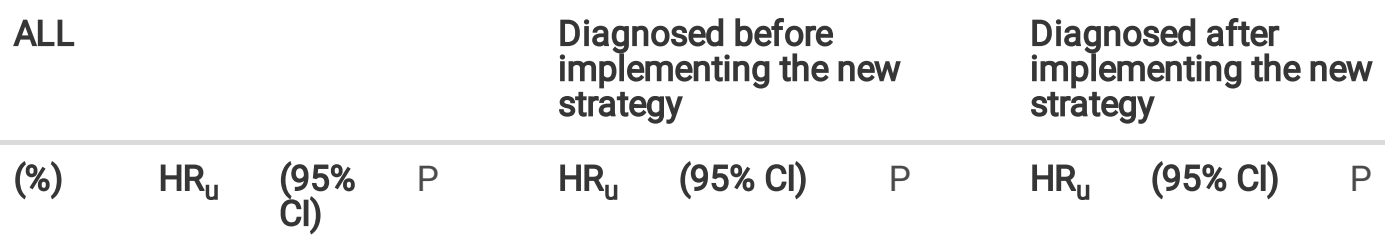

Socio-demographic

characteristics

Age (years)

\begin{tabular}{|c|c|c|c|c|c|c|c|c|c|c|}
\hline$<=25$ & (79.2) & 1.00 & & & 1.00 & & & 1.00 & & \\
\hline $25 \sim 35$ & (81.4) & 1.08 & $\begin{array}{l}(0.83, \\
1.42)\end{array}$ & 0.564 & 1.04 & $\begin{array}{l}(0.62, \\
1.72)\end{array}$ & 0.896 & 1.28 & $\begin{array}{l}(0.93, \\
1.77)\end{array}$ & 0.131 \\
\hline$>35$ & (88.7) & 1.30 & $\begin{array}{l}(0.98, \\
1.72)\end{array}$ & 0.068 & 1.71 & $\begin{array}{l}(1.02, \\
2.87)\end{array}$ & 0.043 & 1.20 & $\begin{array}{l}\text { (0.86, } \\
1.69)\end{array}$ & 0.282 \\
\hline
\end{tabular}

Current marital status

\begin{tabular}{|c|c|c|c|c|c|c|c|c|c|c|}
\hline Single & $(80.0)$ & 1.00 & & & 1.00 & & & 1.00 & & \\
\hline Married/cohabitation & $(86.4)$ & 1.30 & $\begin{array}{l}(1.02, \\
1.67)\end{array}$ & 0.037 & 1.99 & $\begin{array}{l}(1.27, \\
3.11)^{\prime}\end{array}$ & 0.003 & 0.99 & $\begin{array}{l}(0.73 \\
1.34)\end{array}$ & 0.963 \\
\hline Separated/divorced/other & $(92.5)$ & 1.35 & $\begin{array}{l}(0.99 \\
1.84)\end{array}$ & 0.061 & 1.66 & $\begin{array}{l}(0.96 \\
2.87)\end{array}$ & 0.071 & 1.16 & $\begin{array}{l}(0.80 \\
1.70)\end{array}$ & 0.436 \\
\hline
\end{tabular}

Residential district

$\begin{array}{lllllllllll}\text { Urban } & (86.5) & \mathbf{1 . 0 0} & & & 1.00 & & & & & \\ \text { Suburb } & (75.6) & \mathbf{0 . 7 5} & \mathbf{( 0 . 5 9 ,} & \mathbf{0 . 0 2 0} & 0.72 & (0.47, & 0.138 & \mathbf{0 . 7 3} & \mathbf{( 0 . 5 5 ,} & \mathbf{0 . 0 3 2}\end{array}$

HIV infection-related

conditions

HIV transmission mode

\begin{tabular}{|c|c|c|c|c|c|c|c|c|c|c|}
\hline Heterosexual & (79.8) & 1.00 & & & 1.00 & & & 1.00 & & \\
\hline Homosexual & $(85.0)$ & 1.14 & $\begin{array}{l}(0.87, \\
1.48)\end{array}$ & 0.341 & 0.69 & $\begin{array}{l}(0.46 \\
1.05)\end{array}$ & 0.087 & 1.45 & $\begin{array}{l}(1.03, \\
2.06)\end{array}$ & 0.034 \\
\hline Others & (75.0) & 0.89 & $\begin{array}{l}(0.51, \\
1.55)\end{array}$ & 0.667 & 0.53 & $(0.23,1.2)$ & 0.126 & 2.06 & $\begin{array}{l}(0.96, \\
4.42)\end{array}$ & 0.063 \\
\hline
\end{tabular}

Latest CD4 cell counts

\begin{tabular}{|c|c|c|c|c|c|c|c|c|c|c|}
\hline$<=350$ & (85.8) & 1.00 & & & 1.00 & & & 1.00 & & \\
\hline $350-500$ & (81.0) & 0.74 & $\begin{array}{l}(0.58, \\
0.94)\end{array}$ & 0.014 & 0.82 & $\begin{array}{l}(0.53, \\
1.25)\end{array}$ & 0.354 & 0.89 & $\begin{array}{l}(0.65, \\
1.21)\end{array}$ & 0.448 \\
\hline$>500$ & (78.1) & 0.63 & $\begin{array}{l}(0.46, \\
0.86)\end{array}$ & 0.003 & 0.69 & $\begin{array}{l}(0.42, \\
1.14)\end{array}$ & 0.151 & 0.81 & $\begin{array}{l}(0.53, \\
1.23)\end{array}$ & 0.322 \\
\hline
\end{tabular}




\begin{tabular}{|c|c|c|c|c|c|c|c|c|c|c|c|c|}
\hline & \multicolumn{4}{|l|}{ ALL } & \multicolumn{4}{|c|}{$\begin{array}{l}\text { Diagnosed before implementing } \\
\text { the new strategy }\end{array}$} & \multicolumn{4}{|c|}{$\begin{array}{l}\text { Diagnosed after implementing } \\
\text { the new strategy }\end{array}$} \\
\hline & (\%) & $\mathrm{HR}_{\mathrm{u}}$ & $\begin{array}{l}(95 \% \\
\mathrm{Cl})\end{array}$ & $P$ & (\%) & $H R_{u}$ & $\begin{array}{l}(95 \% \\
\mathrm{Cl})\end{array}$ & $P$ & (\%) & $\mathrm{HR}_{\mathrm{u}}$ & $\begin{array}{l}(95 \% \\
\mathrm{Cl})\end{array}$ & $P$ \\
\hline \multicolumn{13}{|l|}{$\begin{array}{l}\text { Self-reported } \\
\text { health status }\end{array}$} \\
\hline $\begin{array}{l}\text { Very } \\
\text { good/good }\end{array}$ & $(80.4)$ & 1.00 & & & (72.9) & 1.00 & & & $(85.7)$ & 1.00 & & \\
\hline $\begin{array}{l}\text { Not good or } \\
\text { poor }\end{array}$ & (84.0) & 1.13 & $\begin{array}{l}(0.91 \\
1.42)\end{array}$ & 0.269 & (71.8) & 1.02 & $\begin{array}{l}(0.69 \\
1.50)\end{array}$ & 0.926 & $(90.1)$ & 1.10 & $\begin{array}{l}(0.84 \\
1.45)\end{array}$ & 0.498 \\
\hline Poor/very poor & (93.3) & 1.60 & $\begin{array}{l}(1.07 \\
2.41)\end{array}$ & 0.023 & (88.9) & 1.85 & $\begin{array}{l}(0.88 \\
3.92)\end{array}$ & 0.107 & (95.2) & 1.34 & $\begin{array}{l}(0.82 \\
2.18)\end{array}$ & 0.240 \\
\hline $\begin{array}{l}\text { Time since } \\
\text { diagnosis of } \\
\text { HIV infection }\end{array}$ & & N.A. & & & & & & & & & & \\
\hline Within 2 years & & & & & (75.8) & 1.00 & & & & & & \\
\hline $\begin{array}{l}\text { More than } \\
2 \text { years }\end{array}$ & & & & & $(71.4)$ & 0.96 & $\begin{array}{l}(0.66 \\
1.4)\end{array}$ & 0.836 & & & & \\
\hline $\begin{array}{l}\text { Time since } \\
\text { diagnosis of } \\
\text { HIV infection }\end{array}$ & & N.A. & & & & & & & & & & \\
\hline Within 15 days & & & & & & & & & (91.5) & 1.00 & & \\
\hline $\begin{array}{l}\text { More than } 15 \\
\text { days }\end{array}$ & & & & & & & & & (77.1) & 0.56 & $\begin{array}{l}(0.39 \\
0.79)\end{array}$ & 0.001 \\
\hline \multicolumn{13}{|l|}{$\begin{array}{l}\text { Time of HIV } \\
\text { diagnosis }\end{array}$} \\
\hline $\begin{array}{l}\text { Before } \\
\text { implementing } \\
\text { the new } \\
\text { strategy }\end{array}$ & (73.3) & 1.00 & & & & N.A. & & & & N.A. & & \\
\hline $\begin{array}{l}\text { After } \\
\text { implementing } \\
\text { the new } \\
\text { strategy }\end{array}$ & $(88.9)$ & 2.04 & $\begin{array}{l}(1.62 \\
2.58)\end{array}$ & $\dot{0} 001$ & & & & & & & & \\
\hline $\begin{array}{l}\text { Variables which } \\
\text { monthly income }\end{array}$ & $\begin{array}{l}\text { ere non- } \\
M B), \text { hc }\end{array}$ & $\begin{array}{l}\text { ynifica } \\
\text { seholc }\end{array}$ & $\begin{array}{l}\text { nt in all a } \\
\text { registrat }\end{array}$ & $\begin{array}{l}\text { nalyses } \\
\text { on. }\end{array}$ & vere not & sted in & nis tabl & includir & sex, eth & icity, e & ucation, & \\
\hline
\end{tabular}

In univariate analysis of pre-scaleup group (Table 3), predictors of ART initiation include: older age, married/cohabitated with others, and self-identified as homosexual transmission. In a multivariate analysis (data not tabulated), participants who were married or cohabitant with others $\left(\mathrm{HR}_{\mathrm{m}}=1.96,95 \% \mathrm{Cl}: 1.25\right.$ to $\left.3.07, p=0.003\right)$ were more likely to initiate ART than those who were single. In similar analysis of post-scaleup group (Table 3), participants who were living in suburban $\left(\mathrm{HR}_{\mathrm{m}}=0.73,95 \%\right.$ C.I.: 0.55 to $0.97, p=0.032)$ and those who had more than 15 days of time interval since HIV diagnosis $\left(\mathrm{HR}_{\mathrm{m}}=0.56,95 \%\right.$ C.I.: 0.40 to $0.80, p=0.001$ ) were less likely to initiate ART than their counterparts. There was no significant difference for latest CD4 levels in subgroup analyses between pre-and post-scaleup groups. 


\section{The predictive effect of ART-related cognition variables on ART initiation}

In univariate analysis of all participants, all constructs of HBM-related ART perceptions were predictors of ART initiation $\left(\mathrm{HR}_{\mathrm{u}}=0.86\right.$ to $\left.1.38, p<0.05\right)$. After adjusting for significant background variables, only the construct of self-efficacy (adjusted $\mathrm{HR}\left(\mathrm{HR}_{\mathrm{a}}\right)=1.23,95 \% \mathrm{Cl}: 1.06$ to $\left.1.43, p=0.006\right)$ was significantly associated with ART initiation.

In univariate analyses of pre-scaleup group, participants who perceived higher severity $\left(\mathrm{HR}_{\mathrm{u}}=1.43,95 \%\right.$ C.I.: 1.10 to $1.86, p=$ 0.007), higher benefits $\left(\mathrm{HR}_{\mathrm{u}}=1.66,95 \%\right.$ C.I.: 1.23 to $\left.2.24, p=0.001\right)$, and higher self-efficacy $\left(\mathrm{HR}_{\mathrm{u}}=1.45,95 \%\right.$ C.I.: 1.15 to 1.84 , $p=0.002)$ are more likely to initiate ART, and those who perceived higher barriers $\left(\mathrm{HR}_{\mathrm{u}}=0.70,95 \%\right.$ C.I.: 0.53 to $\left.0.91, p=0.007\right)$ are less likely to initiate ART. The perceived susceptibility showed no predictive effect of ART initiation. Adjusting for significant background variables, all constructs of HBM-related ART perceptions were still predictors of ART initiation $\left(\mathrm{HR}_{\mathrm{a}}=0.71\right.$ to $\left.1.83, p<0.05\right)$ (Table 4$)$.

Table 4

Associations between the HBM-related ART perceptions and ART initiation

\begin{tabular}{|c|c|c|c|c|c|c|c|c|c|c|c|c|}
\hline & \multicolumn{5}{|l|}{ All } & \multicolumn{4}{|c|}{$\begin{array}{l}\text { Diagnosed before } \\
\text { implementing the new } \\
\text { strategy }\end{array}$} & \multicolumn{3}{|c|}{$\begin{array}{l}\text { Diagnosed after } \\
\text { implementing the new } \\
\text { strategy }\end{array}$} \\
\hline & $\begin{array}{l}\mathrm{HR}_{\mathrm{u}} \\
(95 \% \\
\mathrm{Cl})\end{array}$ & $\mathrm{P}$ & $\begin{array}{l}\mathrm{HR}_{\mathrm{a}} \\
(95 \% \\
\mathrm{Cl})\end{array}$ & $\mathrm{P}$ & $\begin{array}{l}\mathrm{HR}_{\mathrm{u}} \\
(95 \% \\
\mathrm{Cl})\end{array}$ & $\mathrm{P}$ & $\begin{array}{l}\mathrm{HR}_{\mathrm{a}} \\
(95 \% \\
\mathrm{Cl})\end{array}$ & $\mathrm{P}$ & $\begin{array}{l}\mathrm{HR}_{\mathrm{u}} \\
(95 \% \\
\mathrm{Cl})\end{array}$ & $\mathrm{P}$ & $\begin{array}{l}\mathrm{HR}_{\mathrm{a}} \\
(95 \% \\
\mathrm{Cl})\end{array}$ & $P$ \\
\hline $\begin{array}{l}\text { Perceived } \\
\text { severity }\end{array}$ & $\begin{array}{l}1.32 \\
(1.13 \\
1.54)\end{array}$ & 0.001 & $\begin{array}{l}1.17 \\
(0.99 \\
1.38)\end{array}$ & 0.060 & $\begin{array}{l}1.43 \\
(1.10 \\
1.86)\end{array}$ & 0.007 & $\begin{array}{l}1.54 \\
(1.17 \\
2.02)^{\prime}\end{array}$ & 0.002 & $\begin{array}{l}1.03 \\
(0.83 \\
1.27)\end{array}$ & 0.797 & $\begin{array}{l}0.99 \\
(0.80 \\
1.23)\end{array}$ & 0.957 \\
\hline $\begin{array}{l}\text { Perceived } \\
\text { susceptibility }\end{array}$ & $\begin{array}{l}1.18 \\
(1.02 \\
1.37)\end{array}$ & 0.029 & $\begin{array}{l}1.09 \\
(0.94 \\
1.27)\end{array}$ & 0.251 & $\begin{array}{l}1.24 \\
(0.96 \\
1.61)\end{array}$ & 0.096 & $\begin{array}{l}1.34 \\
(1.02 \\
1.75)\end{array}$ & 0.034 & $\begin{array}{l}1.03 \\
(0.86 \\
1.24)\end{array}$ & 0.746 & $\begin{array}{l}1.00 \\
(0.84 \\
1.19)\end{array}$ & 0.990 \\
\hline $\begin{array}{l}\text { Perceived } \\
\text { benefits }\end{array}$ & $\begin{array}{l}1.28 \\
(1.08 \\
1.52)\end{array}$ & 0.005 & $\begin{array}{l}1.15 \\
(0.97 \\
1.38)\end{array}$ & 0.117 & $\begin{array}{l}1.66 \\
(1.23 \\
2.24)\end{array}$ & 0.001 & $\begin{array}{l}1.83 \\
(1.34 \\
2.51)\end{array}$ & $\hat{0} .001$ & $\begin{array}{l}0.95 \\
(0.76 \\
1.19)\end{array}$ & 0.647 & $\begin{array}{l}0.92 \\
(0.74 \\
1.15)\end{array}$ & 0.459 \\
\hline $\begin{array}{l}\text { Perceived } \\
\text { barriers }\end{array}$ & $\begin{array}{l}0.86 \\
(0.74 \\
0.99)\end{array}$ & 0.039 & $\begin{array}{l}0.91 \\
(0.79 \\
1.06)\end{array}$ & 0.216 & $\begin{array}{l}0.70 \\
(0.53 \\
0.91)\end{array}$ & 0.008 & $\begin{array}{l}0.71 \\
(0.55 \\
0.93)\end{array}$ & 0.014 & $\begin{array}{l}1.00 \\
(0.84 \\
1.19)\end{array}$ & 0.991 & $\begin{array}{l}0.98 \\
(0.83 \\
1.17)\end{array}$ & 0.824 \\
\hline Self-efficacy & $\begin{array}{l}1.38 \\
(1.20 \\
1.60)\end{array}$ & <. 001 & $\begin{array}{l}1.23 \\
(1.06 \\
1.43)\end{array}$ & 0.006 & $\begin{array}{l}1.45 \\
(1.15 \\
1.84)\end{array}$ & 0.002 & $\begin{array}{l}1.56 \\
(1.23 \\
1.97)\end{array}$ & $<.001$ & $\begin{array}{l}1.11 \\
(0.92 \\
1.35)\end{array}$ & 0.272 & $\begin{array}{l}1.06 \\
(0.87 \\
1.29)\end{array}$ & 0.576 \\
\hline
\end{tabular}

In univariates and adjusted analyses of post-scaleup group, none of the constructs of HBM-related ART perceptions has predictive effect on ART initiation ( $p>0.05$ ) (Table 4).

\section{Interaction}

Two out of the five models presented statistically significant interaction effect (Table 5): interaction between time of HIV diagnosis and perceived severity $(\beta=-0.36, p=0.038$, Fig. 1$)$, and interaction between time of HIV diagnosis and perceived benefits $(\beta=-0.58, p=0.002$, Fig. 1). One out of the 5 models presented marginally statistically significant interaction effect (the time of HIV diagnosis and perceived barriers $(\beta=0.30, p=0.065$, Fig. 1)) (Table 5). 
Interaction between HBM-related ART perceptions and time of HIV diagnosis on ART initiation ${ }^{\text {a }}$

\begin{tabular}{|c|c|c|c|}
\hline & Beta & SE(Beta) & $P$ \\
\hline \multicolumn{4}{|l|}{ Model 1} \\
\hline Perceived severity & 0.35 & 0.13 & 0.009 \\
\hline Time of HIV diagnosis ${ }^{b}$ & 2.08 & 0.72 & 0.004 \\
\hline Perceived severity * Time of HIV diagnosis & -0.36 & 0.17 & 0.038 \\
\hline \multicolumn{4}{|l|}{ Model 2} \\
\hline Perceived susceptibility & 0.22 & 0.13 & 0.096 \\
\hline Time of HIV diagnosis & 1.56 & 0.69 & 0.024 \\
\hline Time of HIV diagnosis * Perceived susceptibility & -0.22 & 0.16 & 0.181 \\
\hline \multicolumn{4}{|l|}{ Model 3} \\
\hline Perceived benefits & 0.49 & 0.15 & 0.002 \\
\hline Time of HIV diagnosis & 3.06 & 0.81 & $<0.001$ \\
\hline Time of HIV diagnosis * Perceived benefits & -0.58 & 0.19 & 0.002 \\
\hline \multicolumn{4}{|l|}{ Model 4} \\
\hline Perceived barriers & -0.30 & 0.14 & 0.026 \\
\hline Time of HIV diagnosis & -0.29 & 0.53 & 0.581 \\
\hline Time of HIV diagnosis * Perceived barriers & 0.30 & 0.16 & 0.065 \\
\hline \multicolumn{4}{|l|}{ Model 5} \\
\hline Self-efficacy & 0.31 & 0.12 & 0.011 \\
\hline Time of HIV diagnosis & 1.34 & 0.51 & 0.008 \\
\hline Time of HIV diagnosis * Self-efficacy & -0.24 & 0.16 & 0.131 \\
\hline \multicolumn{4}{|c|}{$\begin{array}{l}\text { a Each interaction model included time of HIV diagnosis, one of HBM-related ART perceptions variables and their } \\
\text { interaction term, after adjusting for significant background variables in the multivariate analyses (District, Latest CD } 4 \\
\text { count). }\end{array}$} \\
\hline
\end{tabular}

\section{Discussion}

This study was one of the first studies to investigate the ART initiation in a cohort among ART naïve PLWH. The results revealed that ART initiation rate was differentiated by the HIV diagnosis period and a great gap of the median time interval from enrollment to ART initiation was also identified between the two subgroups. In comparison, the ART initiation rate in the post-scaleup group is close to the $90 \%$ target, but the pre-scaleup group still has a large gap. Developing targeted interventions for ART naïve PLWH who were diagnosed before the new strategy might be beneficial for achieving the second 90 target-90\% ART coverage. 
The high levels of HBM-related ART perceptions in this study may possibly be explained by the increased evidence of less side effect and more health benefits of ART [3,4]. We found that the participants in the post-scaleup group have more favorable ART-related perceptions than those in the pre-scaleup group in all constructs. Several reasons might account for such difference. First, the post-scaleup group received the latest and consistent ART knowledge, while the pre-scaleup group experienced multiple changes in treatment strategies, and ART knowledge obtained may be diverse and inconsistent. Second, the participants in the pre-scaleup group might still under the impression that early treatment was harmful to health and may lead to early drug resistance even if the treatment strategy changed. It may be hard to change the established perception. Third, due to the possible inadequate health promotion of the new strategies, the previously diagnosed PLWH might not comprehensively and accurately understand the new strategies. Therefore, it is necessary to conduct in-depth qualitative and quantitative research to understand the perceptions of HIV patients who diagnosed before the new strategy and to guide the future intervention designs to promote treatment.

Previous studies suggested that ART-related perceptions can be modified to promote the actual ART initiation behavior [13, $14,29,36-40]$. The different perception levels between the two subgroups might primarily contribute to different ART initiations. Therefore, forming favorable ART-related perceptions for the pre-scaleup group may have a positive effect on ART initiation. Future research may consider using HBM for guiding intervention designs [31], such as delivering the information based on the mobile platform [41], designing short and user-friendly articles and vivid videos [42], developing a website and telephone service platform to provide more convenient consultation and support for PLWH [43], promoting advocacy in specific groups through peer support $[44,45]$, promoting ART initiation by supporting medical staff with knowledge, training and management skills and integrating such skills into PLWH's routine care service [46].

In addition, we found that HBM-related ART perceptions had different predictive effects on the ART initiation in different subgroups. In the pre-scaleup group, HBM-related ART perceptions have a predictive effect on the ART initiation, but in the post-scaleup group, there was no significant predictive effect. The reason may be that post-scaleup group has reached a higher level of HBM-related ART perceptions and the variation is not enough to explain the treatment behavior, and the prescaleup group experienced multiple changes in treatment strategies and the perception variation was large [47, 48]. Therefore, under the new strategy it may be critical to promoting the proper perceptions for the patients who diagnosed before the new ART strategy. For the post-scaleup group, implementing the immediate ART initiation program [49], increasing the accessibility of treatment could promote the ART coverage in suburban area, given that PLWH who were diagnosed with HIV within 15 days (91.5\% vs $77.1 \%$ ) and those living in urban ( $97.2 \%$ vs $80.5 \%)$ have higher treatment rate than others.

We found an interaction effect of the time of HIV diagnosis and HBM-related ART perceptions on ART initiation. According to the interaction diagram, no interaction effect of HBM-related ART perceptions and time of HIV diagnosis was found in postscaleup group, but such interaction effect was suggested in the pre-scaleup group, which is consistent with the analyses of the effects of HBM-related ART perceptions on treatment behavior in subgroups.

In this study, we didn't find the predictive effect of CD4 levels on ART initiation among all participants and subgroup analysis. Although we observed that the higher latest CD4 levels had the lowest treatment rate of all PLWH, such association was not significant after adjusting for the time of HIV diagnosis. This result is inconsistent with previous studies which showed that higher CD4 levels was negatively associated with ART initiation [12]. The unobserved treatment disparity of different CD4 groups in initiating ART is quite promising.

This study has several limitations. First, we only analyzed the predictive effects of background variables and HBM-related ART perceptions on ART initiation and did not involve other factors such as psychosocial variables. Future research may consider these aspects. Second, the study defined the time to ART initiation as the interval between baseline enrollment and actual ART uptake, instead of the time interval from HIV diagnosis to ART initiation. It may not be able to directly examine the impact of new strategy on ART uptake behaviors. Third, we analyzed the ART initiation and its predictors in the two subgroups, but the imbalance in the number of cases in two subgroups may cause insufficient efficacy. Finally, the data collected by the baseline survey was self-reported data and there may be reporting bias.

Page 16/23 


\section{Conclusions}

In summary, ART initiation, HBM-related ART perceptions and predictive effect of perceptions on ART initiation were different among PLWH diagnosed at different time periods. ART coverage was high under the new strategy, especially among participants who diagnosed after the new treatment strategy. However, a gap still exists referring to the $95 \%$ treatment rate target in 2030 [50], especially in the pre-scaleup group. The important role of the time of HIV diagnosis on ART initiation identified in this study suggested that future implementation interventions may consider to modify the ART-related perceptions for HIV patients who diagnosed before the implementation of the new ART strategy, while expand the accessibility of ART service for those who diagnosed after the implementation of the new strategy.

\section{List Of Abbreviations}

Antiretroviral therapy (ART)

People living with HIV (PLWH)

Men who have sex with men (MSM)

Joint United Nations program on AIDS/HIV (UNAIDS)

Health Belief Model (HBM)

World Health Organization (WHO)

Centers for Disease Control and Prevention (CDC)

Community Healthcare Centers (CHCs)

Standard deviation (SD)

Hazard Ratio (HR)

Multivariate $\mathrm{HR}\left(\mathrm{HR}_{\mathrm{m}}\right)$

Univariate $\mathrm{HR}\left(\mathrm{HR}_{\mathrm{u}}\right)$

Adjusted HR $\left(\mathrm{HR}_{\mathrm{a}}\right)$

\section{Declarations}

\section{Ethics approval and consent to participate}

The study protocol was reviewed and approved by the Institutional Review Board (IRB) of the School of Public Health, Sun Yat-sen University, Guangzhou, China (No: 2016-003). All subjects gave their informed consent for inclusion before they participated in the study.

\section{Consent for publication}

Not applicable.

\section{Availability of data and materials}

Page $17 / 23$ 
The datasets used and/or analysed during the current study is available from the corresponding author on reasonable request.

\section{Competing interests}

YTH is a member of the editorial board of BMC Infectious Diseases and others authors have no competing interests to declare.

\section{Funding}

The study was supported by the National Natural Science Foundation Project (\#71774178), Science and Technology Planning Project of Guangzhou city (\#201607010368), Science and Technology Planning Project of Guangdong Province (\#2017A020212006), Comprehensive prevention and treatment of AIDS, viral hepatitis and tuberculosis communities Project of Guangdong Province (\#2018ZX10715004).

\section{Authors' contributions}

TY analyzed the data, edited and revised the manuscript. JG and XD conceived and designed the study and performed the research. LL, HX, LF and QL contributed to data collection and interpretation. XY critically reviewed the manuscript for important intellectual content and revised the manuscript. $\mathrm{CH}, \mathrm{JL}, \mathrm{YH}, \mathrm{XF}$ and $\mathrm{WC}$ reviewed the manuscript. All authors have read and approved the final version.

\section{Acknowledgements}

We thank the medical staff of the Center for Disease Control and Prevention, Community Healthcare Centers (CHCs) and all participants in the study.

\section{References}

1. World Health Organization(WHO). HIV/AIDS.Data and statistics[Internet]. 2019. Available from: https://wwwwhoint/news-room/fact-sheets/detail/hiv-aids/(accessed 20 Oct 2019).

2. Lundgren JD, Babiker AG, Gordin F, Emery S, Grund B, Sharma S, et al. Initiation of Antiretroviral Therapy in Early Asymptomatic HIV Infection. The New England journal of medicine. 2015;373(9):795-807.

3. Danel C, Moh R, Gabillard D, Badje A, Le Carrou J, Ouassa T, et al. A Trial of Early Antiretrovirals and Isoniazid Preventive Therapy in Africa. The New England journal of medicine. 2015;373(9):808-22.

4. Grinsztejn B, Hosseinipour MC, Ribaudo HJ, Swindells S, Eron J, Chen YQ, et al. Effects of early versus delayed initiation of antiretroviral treatment on clinical outcomes of HIV-1 infection: results from the phase 3 HPTN 052 randomised controlled trial. The Lancet Infectious diseases. 2014;14(4):281-90.

5. World Health Organization. Guideline on when to start antiretroviral therapy and on pre-exposure prophylaxis for HIV [Internet]. 2015. Available from: http://apps.who.int/iris/bitstream/10665/186275/1/9789241509565/en.pdf/(accessed 20 Oct 2019).

6. World Health Organization. 2018 Global AIDS Update slides (Part 3) I UNAIDS [Internet]. 2018. Available from: https://www.unaids.org/en/resources/documents/2018/2018-global-aids-update-slides-part3/en.pdf/ (accessed 20 Oct 2019)..

7. National Health Commission of the People's Republic of China. China's progress in AIDS prevention and treatment [Internet]. 2018. Available from: 
http://www.nhc.gov.cn/zhuz/xwfb/201811/5fe377b577d04d369a057970c0f816d1.shtml/ (accessed 20 Oct 2019 ).

8. National Health Commission of the People's Republic of China. National Health and Family Planning Commission of the People's Republic of China announcement on standard of antiretroviral treatment (in Chinese) [Internet]. 2016. Available from:http://www.nhfpc.gov.cn/yzygj/s3593/201606/0b0fa78e10dc41328e842b1bf9cd433e.shtml/ (accessed 20 Oct 2019).

9. Mujugira A, Celum C, Thomas KK, Farquhar C, Mugo N, Katabira E, et al. Delay of antiretroviral therapy initiation is common in East African HIV-infected individuals in serodiscordant partnerships. Journal of acquired immune deficiency syndromes (1999). 2014;66(4):436-42.

10. Mao L, de Wit J, Kippax S, Prestage G, Holt M. Younger age, recent HIV diagnosis, no welfare support and no annual sexually transmissible infection screening are associated with nonuse of antiretroviral therapy among HIV-positive gay men in Australia. 2015;16(1):32-7.

11. Sun J, Liu L, Shen J, Chen P, Lu HJBID. Trends in baseline CD4 cell counts and risk factors for late antiretroviral therapy initiation among HIV-positive patients in Shanghai, a retrospective cross-sectional study. 2017;17(1):285.

12. Lee MJ, Venturelli S, McKenna W, Teh J, Negedu O, Florman KE, et al. Reasons for delayed antiretroviral therapy (ART) initiation in the era of early ART initiation guidelines: a retrospective service evaluation. 2019;30(4):415-8.

13. Hollingdrake O, Lui CW, Mutch A, Dean J, Howard C, Fitzgerald L. Factors affecting the decision to initiate antiretroviral therapy in the era of treatment-as-prevention: synthesis of evidence from qualitative research in high-income settings. AIDS care. 2019;31(4):397-402.

14. Ahmed S, Autrey J, Katz IT, Fox MP, Rosen S, Onoya D, et al. Why do people living with HIV not initiate treatment? A systematic review of qualitative evidence from low- and middle-income countries. Soc Sci Med. 2018;213:72-84.

15. Poudel KC, Buchanan DR, Poudel-Tandukar K. Delays in antiretroviral therapy initiation among HIV-positive individuals: results of the positive living with HIV study. Global health action. 2016;9:31550.

16. Velloza J, Celum C, Haberer JE, Ngure K, Irungu E, Mugo N, et al. Depression and ART Initiation Among HIV Serodiscordant Couples in Kenya and Uganda. AIDS and behavior. 2017;21(8):2509-18.

17. Tao J, Vermund SH, Lu H, Ruan Y, Shepherd BE, Kipp AM, et al. Impact of Depression and Anxiety on Initiation of Antiretroviral Therapy Among Men Who Have Sex with Men with Newly Diagnosed HIV Infections in China. AIDS patient care and STDs. 2017;31(2):96-104.

18. Teklu AM, Delele K, Abraha M, Belayhun B, Gudina EK, Nega A. Exploratory Analysis of Time from HIV Diagnosis to ART Start, Factors and effect on survival: A longitudinal follow up study at seven teaching hospitals in Ethiopia. Ethiopian Journal of Health Sciences. 2017;27:17-28.

19. Plazy M, Dabis F, Naidu K, Orne-Gliemann J, Barnighausen T, Dray-Spira R. Change of treatment guidelines and evolution of ART initiation in rural South Africa: data of a large HIV care and treatment programme. BMC infectious diseases. 2015;15:452.

20. Xu MJ, Zhao Y, Zhao DC, Ma Y. [Immediate antiretrovial therapy and its predictors among HIV-infected adolescents through sexual transmission,2012-2017,China].Zhon guo ai zi bing xing bing za zhi[Chinese journal of preventive medicine]. 2019;25(04):346-9.

21. Yang $X$, Wang Z, Wang X, Ma T, Xue H, He Y, et al. Behavioral Intention to Initiate Antiretroviral Therapy (ART) Among Chinese HIV-Infected Men Who Have Sex With Men Having High CD4 Count in the Era of "Treatment for All". American journal of men's health. 2019;13(1):1557988319828615.

22. The Joint United Nations Programme on HIV and AIDS. 90-90-90 An ambitious treatment target to help end the AIDS epidemic [Internet]. Geneva SUAfhwu. Available from:https://www.unaids.org/sites/default/files/media_asset/90-9090/en.pdf/ (accessed 20 Oct 2019).

23. Rodger AJ, Phillips A, Speakman A, Gilson R, Fisher M, Wilkins E, et al. Attitudes of people in the UK with HIV who Are Antiretroviral (ART) Naive to starting ART at high CD4 counts for potential health benefit or to prevent HIV transmission. PloS one. 2014;9(5):e97340.

Page $19 / 23$ 
24. Holt M, Lea T, Murphy DA, Ellard J, Rosengarten M, Kippax SC, et al. Australian gay and bisexual men's attitudes to HIV treatment as prevention in repeated, national surveys, 2011-2013. PloS one. 2014;9(11):e112349.

25. Jiang HH, Lu F, He HJ, Zhang DD, Zeng G, Xu P, et al. [Acceptability status of early antiretroviral therapy among HIVpositive men who have sex with men]. Zhonghua yu fang yi xue za zhi [Chinese journal of preventive medicine]. 2013;47(9):843-7.

26. Zhang Q, Tang Z, Sun H, Cheng P, Qin Q, Fan Y, et al. Acceptability of early anti-retroviral therapy among HIV-infected people in Anhui province in China. AIDS care. 2015;27(5):669-74.

27. Albarracin D, Johnson BT, Fishbein M, Muellerleile PA. Theories of reasoned action and planned behavior as models of condom use: a meta-analysis. Psychological bulletin. 2001;127(1):142-61.

28. Sheeran P, Taylor S. Predicting Intentions to Use Condoms: A Meta-Analysis and Comparison of the Theories of Reasoned Action and Planned Behavior12006. 1624-75 p.

29. Gebru T, Lentiro K, Jemal A. Perceived behavioural predictors of late initiation to HIV/AIDS care in Gurage zone public health facilities: a cohort study using health belief model. BMC research notes. 2018;11(1):336.

30. Vitalis D. Predicting adherence to antiretroviral therapy among pregnant women in Guyana: Utility of the Health Belief Model. International journal of STD \& AIDS. 2017;28(8):756-65.

31. Adefolalu AO. Cognitive-behavioural theories and adherence: Application and relevance in antiretroviral therapy. Southern African journal of HIV medicine. 2018;19(1):762.

32. Ofori KN. Application of the Health Belief Model to HIV Testing and Counselling Among Youth Living in Selected Rural Communities in Ghana.2019. 11-8 p.

33. Wan LH, You LM, Chen SX, Zhang XP, Mo MM, Zhang YM, et al. The effectiveness of a comprehensive reminder system in the secondary prevention of hypertensive ischaemic stroke: randomized controlled trial protocol. Journal of advanced nursing. 2016;72(12):3195-206.

34. Calloway DS, Long-White DN, Corbin DE. Reducing the risk of HIV/AIDS in African American college students: an exploratory investigation of the efficacy of a peer educator approach. Health promotion practice. 2014;15(2):181-8.

35. Huang L, Yang Q, Hu Q, Huang Q, Jiang XQ, Zhu H, et al. [Analysis on the situation of the AIDS follow-up management of HIV/AIDS in Jiangxi Province]. Zhou hua ji bing kong zhi za zhi [Chinese journal of preventive medicine]. 2017;21(12):1298-300.

36. Abaynew Y, Deribew A, Deribe K. Factors associated with late presentation to HIV/AIDS care in South Wollo ZoneEthiopia: a case-control study. AIDS Res Ther. 2011;8(1):8.

37. Kahn TR, Desmond M, Rao D, Marx GE, Guthrie BL, Bosire R, et al. Delayed initiation of antiretroviral therapy among HIVdiscordant couples in Kenya. AIDS care. 2013;25(3):265-72.

38. Horter S, Wringe A, Thabede Z, Dlamini V, Kerschberger B, Pasipamire M, et al. "Is it making any difference?" A qualitative study examining the treatment-taking experiences of asymptomatic people living with HIV in the context of Treat-all in Eswatini. Journal of the International AIDS Society. 2019;22(1):e25220.

39. Christopoulos KA, Olender S, Lopez AM, Lekas HM, Jaiswal J, Mellman W, et al. Retained in HIV Care But Not on Antiretroviral Treatment: A Qualitative Patient-Provider Dyadic Study. PLoS medicine. 2015;12(8):e1001863.

40. Persson A, Newman CE, Mao L, de Wit J. On the Margins of Pharmaceutical Citizenship: Not Taking HIV Medication in the "Treatment Revolution" Era. Medical anthropology quarterly. 2016;30(3):359-77.

41. Venter W, Coleman J, Chan VL, Shubber Z, Phatsoane M, Gorgens M, et al. Improving Linkage to HIV Care Through Mobile Phone Apps: Randomized Controlled Trial. JMIR Mhealth Uhealth. 2018;6(7):e155.

42. Neumann MS, Plant A, Margolis AD, Borkowf CB, Malotte CK, Rietmeijer CA, et al. Effects of a brief video intervention on treatment initiation and adherence among patients attending human immunodeficiency virus treatment clinics. PloS one. 2018;13(10):e0204599. 
43. Fox MP, Rosen S, Geldsetzer P, Barnighausen T, Negussie E, Beanland R. Interventions to improve the rate or timing of initiation of antiretroviral therapy for HIV in sub-Saharan Africa: meta-analyses of effectiveness. Journal of the International AIDS Society. 2016;19(1):20888.

44. Chang LW, Nakigozi G, Billioux VG, Gray RH, Serwadda D, Quinn TC, et al. Effectiveness of Peer Support on Care Engagement and Preventive Care Intervention Utilization Among Pre-antiretroviral Therapy, HIV-Infected Adults in Rakai, Uganda: A Randomized Trial. AIDS and behavior. 2015;19(10):1742-51.

45. Monroe A, Nakigozi G, Ddaaki W, Bazaale JM, Gray RH, Wawer MJ, et al. Qualitative insights into implementation, processes, and outcomes of a randomized trial on peer support and HIV care engagement in Rakai, Uganda. 2017;17(1):54.

46. Tembo TA, Kim MH, Simon KR, Ahmed S, Beyene T, Wetzel E, et al. Enhancing an HIV index case testing passive referral model through a behavioural skills-building training for healthcare providers: a pre-/post-assessment in Mangochi District, Malawi. Journal of the International AIDS Society. 2019;22(S3):e25292.

47. Down I, Prestage G, Triffitt K, Brown G, Bradley J, Ellard J. Recently diagnosed gay men talk about HIV treatment decisions. Sexual health. 2014;11(2):200-6.

48. Grace D, Chown SA, Kwag M, Steinberg M, Lim E, Gilbert M. Becoming "Undetectable": Longitudinal Narratives of Gay Men's Sex Lives After a Recent HIV Diagnosis. AIDS education and prevention : official publication of the International Society for AIDS Education. 2015;27(4):333-49.

49. World Health Organization (WHO). Guidelines for managing advanced HIV disease and early initiation of antiretroviraltherapy[Internet]. Available from: http://wwwwhoint/hiv/pub/guidelines/advanced-HIV-disease/end.pdf/ (accessed 20 Oct 2019).

50. Granich R, Gupta S, Matt W, Mike R, Brian W. Modeling the HIV Epidemic: Why the 95-95-95 Target and ART Effectiveness Parameters Matter. International Journal of Virology and AIDS. 2018;5.

\section{Figures}



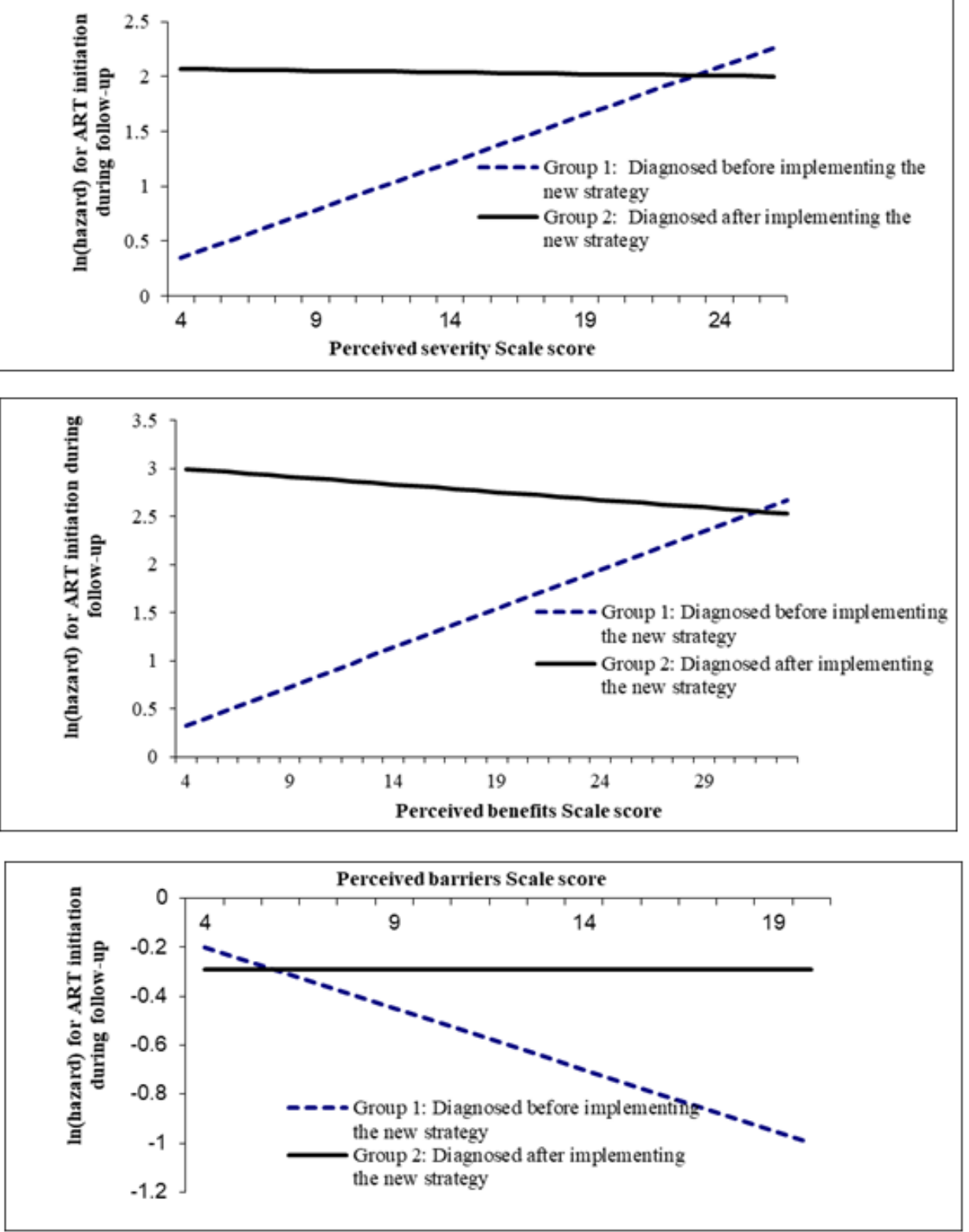

\section{Figure 1}

Interaction between time of HIV diagnosis and Perceived severity scale, Perceived benefits scale and perceived barriers scale, respectively. 

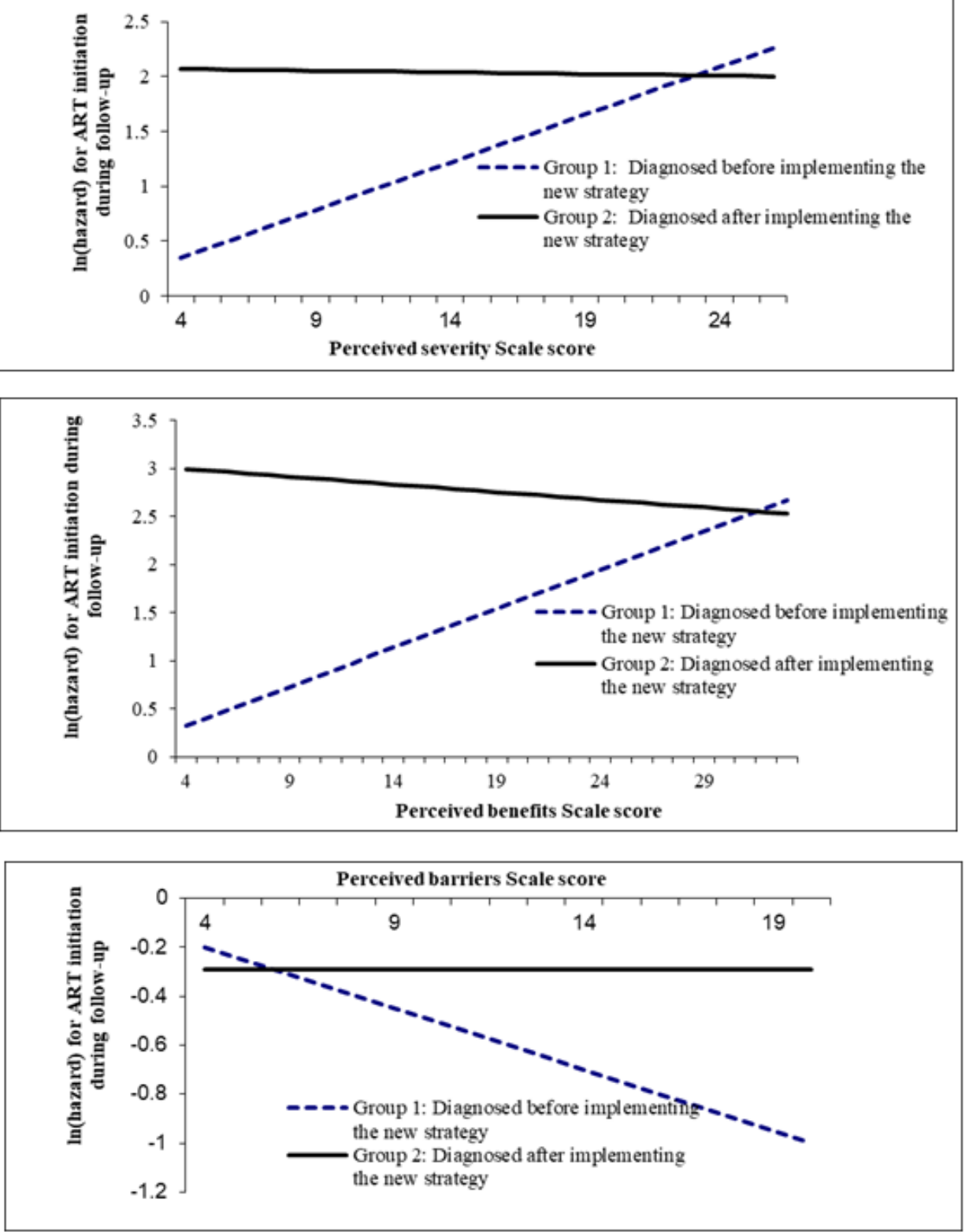

\section{Figure 1}

Interaction between time of HIV diagnosis and Perceived severity scale, Perceived benefits scale and perceived barriers scale, respectively. 